\title{
Determinants of Intra-ASEAN Labour Migration to Thailand
}

\author{
Utis Sanglaoid $^{1}$, Sumalee Santipolvut ${ }^{1} \&$ Rewat Thamma-Apiroam ${ }^{1}$ \\ ${ }^{1}$ Faculty of Economics, Department of Economics, Kasetsart University, Bangkok, Thailand \\ Correspondence: Utis Sanglaoid, Faculty of Economics, Department of Economics, Kasetsart University, 50 \\ Ngamwongwan Rd., Lardyao, Chatuchak, Bangkok 10900, Thailand. Tel: 66-84-041-4409. E-mail: \\ utis24@hotmail.com
}

$\begin{aligned} & \text { Received: December 19, } 2013 \quad \text { Accepted: February 24, } 2014 \quad \text { Online Published: March 26, } 2014 \\ & \text { doi:10.5539/ass.v10n8p66 }\end{aligned}$ URL: http://dx.doi.org/10.5539/ass.v10n8p66

\begin{abstract}
This paper aims at analyzing the determinants of intra-ASEAN labor migration to Thailand, for the period 2002-2010. We apply the well-known Hatton's migration model to our analysis. Having employed panel data through fixed effect model estimations, we find that the GDP gaps between Thailand and the migrant countries, migration stocks which reflect the existence of immigrant networks, and Thailand's migration worker policy all play a crucial role in explaining migration behaviors. A policy implication is that the government of Thailand should pay more attention to its coherent migration worker policy, since it affects the net migration rate, evidently.
\end{abstract}

Keywords: determinants of migration, ASEAN, Thailand

\section{Introduction}

International migration is a major economic issue because labour, which encompasses human capital, is perhaps the most influential factor determining economic growth. Economists and scholars have tried to analyse the causes of voluntary migration through their own methods and specialties. Hatton (1995) created a model to explain emigration concerning the United Kingdom, and he found that economic and demographic factors account for many of the reasons for it. His model was developed and applied to migration in Europe, especially to the expansion period of European countries. Another important contributor to this line of research is Fertig. In 2001, he studied about migration to Germany, during the period of 1960-1994. Having extended Hatton's model, he included factors of free labour migration and utilized alphabetical order and panel data, thereby acquiring a greater number of data points. Pytlikova (2006) studied the migration of seven countries into the European Union in 2002, by retrieving data from 1990 to 2000. Her model was also developed from Hatton's by adding a distance variable, and using alphabetical order and panel data. It was divided into three categories: no difference in each country, a difference of each country and a difference in each country. Ruyssen (2008) studied migration into Eastern Europe. She also modified Hatton's model by including: migrants' voting rights, their duration of holding citizenship, the rates of migration being the responsibility of the target country, numbers of job vacancies and the ratios of skilled and unskilled workers. She also used alphabetical order and panel data with the same three categories: no difference in each country, a difference of each country, and a difference in each country.

Despite international migration existing universally, Asian labour migration is quite distinctive. This is because Asians constitute a substantial portion of the world's population, although Asia's per capita income combined is relatively low. Furthermore, income disparity among countries is noticeable. Likewise, such a pattern also occurs in the case of the Association of South East Asian Nations (ASEAN). ASEAN, which consists of 10 countries, has agreed to become a single economic unit by 2015. It is home to approximately 600 million people in total, but the GDP per capita of the 10 member countries are relatively marginal, when compared to the rest of the world. In addition, a wide gap of income per capita does exist. The range is from 1,254.52 US dollars for Myanmar to 56,708.21 US dollars for Singapore, based upon the 1995 international constant dollars and purchasing parity power (World Bank, 2010). Without doubt, this means substantial income inequality between the two countries. This also holds true when such a comparison is made between Myanmar and Thailand. This is because, in 1995, Thailand was ranked fourth in terms of per-capita income amongst the member countries. The net migration rates to Thailand from Myanmar, Laos, Cambodia and the Philippines are positive. This means that the numbers of laborers from those countries immigrating to Thailand are greater than the numbers of Thai laborers immigrating to the same countries. It is fair to say that economic differentials are plausibly the prime 
reason for labour migration. However, there are other significant factors pertaining to such movements as well. One salient and major factor concerns migration and immigration laws and regulations. As a matter of fact, they differ greatly among the ASEAN member countries. Other reasons worth identifying are: the levels of economic development, job opportunities and government cognizance and political concerns. All of these are neither uniform nor dependent.

These factors, amongst others, largely account for intra-ASEAN migration, although they are subject to confirmation through empirical investigations. Before proceeding to that point, the following theoretical concepts of migration need clarification. Based upon country status, the patterns of international migration can be sorted into three groups. In the case of ASEAN, group one comprises the main source of migrants: Cambodia, Laos, Philippines, Indonesia, Vietnam, and Myanmar, group two comprises their main destination countries: Singapore and Brunei, and group three comprises the countries with significant emigration and immigration rates: Malaysia and Thailand (Hugo, 2005). Thailand lies in a different situation to Malaysia, though classified in the same group; such is its unique underpinning position. As previously mentioned, Myanmar has the lowest income amongst all member states. As a result, its outflows are likely to far exceed its inflows. The further the distance a destination country lies intensifies the problem. Geographically, Thailand is adjacent to Myanmar, and they share a border more than 1,800 kilometers in length. This, together with the fact that Thailand is one of the destination countries, has led to an influx of Myanmar workers to Thailand. In addition, they are the poorest, almost all low-skilled, and have a low level of education, thereby increasing the chance of their being illegal or undocumented workers. This clearly intensifies the migration problem which Thailand constantly encounters. We believe that it has become an urgent requirement to seriously examine the factors determining labour migration to Thailand, with emphasis upon empirical evidence. Also, this intra-ASEAN migration analysis is inspected as both relative and crucial points.

The main objective of this study is to analyse the factors determining labour migration within the ASEAN member states, particularly into Thailand. There are two main points in which our study differs from others. First, we extend Hatton's (1995) time series model of migration determinants, by taking into consideration the immigration policies of the destination country. In doing so, we can estimate the model using a fixed effect scheme, coupled with the use of further observation through panel data. Second, a model of net migration rates from countries in ASEAN to Thailand is used to estimate the number of migrants into Thailand. This includes the net migration rates with a model of the situation leading to impacts upon the Thai economy. The policy makers can benefit from such information for well-planned policy making. In addition, the information can be used more pertinently to plan, develop and implement labour policies. The result, using panel data, shows that the income gaps among ASEAN states and their migration stocks, which reflect the existence of immigrant networks, have strong positive effects upon immigrants from ASEAN countries. Also, the migration worker policy of Thailand has positive effects upon the net migration rates.

The remainder of this paper is organized as follows: Section 2 outlines the theoretical model, introduces brief backgrounds and states the specification employed in this study. Section 3 elaborates upon how we obtain our empirical specification, and provides the estimation results. Section 4 is the conclusion.

\section{Selected Variables and the Theoretical Model}

\subsection{Selected Variables Used in This Study}

The Association of Southeast Asian Nations was established on $8^{\text {th }}$ August 1967, in Bangkok, and signed by the Ministers of 5 countries, namely: Indonesia, Malaysia, the Philippines, Singapore and Thailand. Subsequently, there are 5 additional countries which have joined: Brunei, Vietnam, Laos, Myanmar, and Cambodia. This comprises 10 countries in total.

Some selected variables used in the study are illustrated in Table 1 . The migration worker policy of Thailand directly affects the numbers of migrant laborers. There was one notable policy, from the Thai Ministry of Labour, which stated that only Burmese, Cambodians and Laotians could register for work in Thailand in either 2004 or 2009. This led to higher numbers of foreign workers. In 2003 there were only 296,184 workers, which rose to 858,719 in 2004 . That is a rise of $189.93 \%$. In 2008 there were 529,629 workers, but in 2009 the number rose to $1,435,398$, equivalent to an increase of $171.02 \%$. The stock of immigrants left in Thailand, ranked in order of the top three, are from Myanmar, Laos and Cambodia. From these numbers and the apparent patterns it is clear that distance matters, because all of these countries have common borders with Thailand. Positive net migration rates show that laborers from these countries migrate to Thailand more than Thai laborers migrate to their countries. Those countries also have lower GDPs than Thailand. In contrast, laborers from Brunei, Singapore, Malaysia, and Vietnam migrate to Thailand in lower numbers than Thai laborers migrate to their countries. All of those 
countries have higher GDPs than Thailand, except Vietnam.

The net migration rates of Myanmar, Laos, Cambodia and the Philippines are positive, because the laborers of these countries move to Thailand in greater numbers than Thai workers move to those destinations, respectively. The GDPs of these four countries are lower than that of Thailand. On the contrary, workers from Brunei, Singapore, Malaysia and Vietnam move to Thailand in lower numbers than Thai workers move to those countries, accordingly, and their GDPs are all higher than Thailand's, except Vietnam. There was one notable migration worker policy of Thailand, which stated that only Burmese, Cambodian and Laotian laborers could register for work in Thailand in either 2004 or 2009. This increased the numbers of ASEAN laborers in Thailand, from 296,184 in 2003 to 858,719 in 2004, and from 529,629 in 2008 to 1,435,398 in 2009.

Table 1. Selected variables used in this study

\begin{tabular}{|c|c|c|c|c|c|c|c|c|c|c|}
\hline \multirow[t]{2}{*}{ Country } & \multirow{2}{*}{$\begin{array}{l}\text { GDP per } \\
\text { capita } \\
(\mathrm{PPP})^{*} \\
2010\end{array}$} & \multirow{2}{*}{$\begin{array}{l}\text { Unemployment } \\
\text { rate }(\%) * * \\
2010\end{array}$} & \multicolumn{4}{|c|}{ Stock of ASEAN workers $* * * *$} & \multicolumn{2}{|c|}{$\begin{array}{l}\text { Net migration rate } \\
\text { Thailand }(\%) * * * * *\end{array}$} & \multicolumn{2}{|c|}{ from ASEAN to } \\
\hline & & & 2003 & 2004 & 2008 & 2009 & 2003 & 2004 & 2008 & 2009 \\
\hline Singapore & $56,708.21$ & 2.18 & 11.01 & 13.75 & 22.94 & 16.17 & -24.88 & -60.76 & -26.12 & -24.83 \\
\hline Malaysia & $14,744.34$ & 3.40 & 16.04 & 21.02 & 37.49 & 22.51 & -1.70 & -7.18 & -0.10 & -0.58 \\
\hline $\begin{array}{l}\text { Brunei } \\
\text { Darussalam }\end{array}$ & $48,621.41$ & 2.70 & 0.00 & 0.00 & 0.00 & 0.00 & -162.86 & -360.59 & -87.06 & -98.38 \\
\hline Indonesia & $4,352.61$ & 7.14 & 3.33 & 4.28 & 10.69 & 5.86 & 0.01 & 0.00 & 0.03 & 0.00 \\
\hline Lao People's & & & & & & & & & & \\
\hline Democratic & $2,449.25$ & N/A & 213.14 & $1,052.59$ & 136.70 & $1,611.27$ & 34.04 & 181.62 & 19.76 & 262.42 \\
\hline Republic & & & & & & & & & & \\
\hline Vietnam & $3,142.97$ & 4.29 & 3.67 & 4.08 & 7.27 & 2.93 & -0.08 & -0.25 & -0.05 & -0.03 \\
\hline Myanmar & $1,254.52$ & 4.02 & $2,489.71$ & $6,350.46$ & $4,872.86$ & $10,834.98$ & 54.29 & 137.79 & 103.11 & 227.57 \\
\hline Cambodia & $2,065.37$ & N/A & 196.75 & $1,106.01$ & 120.94 & $1,792.48$ & 15.05 & 83.69 & 8.71 & 128.20 \\
\hline Philippines & $3,920.28$ & 7.33 & 28.19 & 35.00 & 70.91 & 87.40 & 0.32 & 0.37 & 0.95 & 0.72 \\
\hline Thailand & $9,222.39$ & 1.04 & - & - & - & - & - & - & - & - \\
\hline Total & - & - & $2,961.84$ & $8,587.19$ & $5,279.80$ & $14,373.60$ & - & - & - & - \\
\hline
\end{tabular}

Note: * GDP per capita (constant 1995 international \$) based on purchasing power parity (PPP), Source: World Bank; ** Unemployment, total (\% of total labour force), Source: World Bank; **** Stock of foreigners from country i in Thailand per 100, Source: Office of workers administration, Department of Employment, Ministry of Labour; ***** Net migration rate from country i to Thailand per 10,000 inhabitants, Source: Thailand Overseas Employment Admission and Office of workers administration, Department of Employment, Ministry of Labour.

N/A: Not available

\subsection{Theoretical Model of International Migration}

Suppose that the probability of migration of individual (i) from the home country (h) to the foreign country (f) depends on the difference in expected utility streams in the two locations, minus the costs of migration $\left(\mathrm{z}_{\mathrm{i}}\right)$; then we denote this difference by $\mathrm{d}_{\mathrm{i}}$ :

$$
\mathrm{d}_{i h f t}=E_{u\left(y_{f t}\right)}-E_{u\left(y_{h t}\right)}-z_{i t}
$$

Assuming an average probability of migration over all individual (i), the rate of migration $\left(\mathrm{M}_{\mathrm{t}}\right)$ into a given destination country $(j)$ is thus assumed to be a function of net present value:

$$
M_{h f t}=\beta\left(d_{h f t}^{*}\right)
$$

Assume that the costs of migration from (h) to (f) are (negatively) related to the stock of migrant to (f) from country (h) because of network effects (Hatton, 1995). We account distance between home and foreign countries $\left(D_{h f}\right)$ as being pretty much remote, thus it might play a role in migration decision making. As a result, the researchers set up a hypothesis that distance is a vital factor reflecting the decision whether to migrate. Therefore, 
$\bar{Z}$ is the mean of $\mathrm{z}_{\mathrm{i}}$ depending on migration stock at time $(\mathrm{t})$, and the distance between source and target country $\left(D_{\mathrm{hf}}\right)$, as expressed by equation (3):

$$
\overline{Z_{t}}=\mu_{0}-\mu_{1} M S T_{h f t}+\mu_{2} D_{h f}
$$

Hence, the rate of migration becomes equation (4):

$$
M_{h f t}=\beta \lambda \ln \left(\frac{w_{f}}{w_{h}}\right)_{t}+\beta \lambda \frac{t}{2} \ln \left(\frac{\varepsilon_{f}}{e_{h}}\right)_{t}-\beta \lambda \mu_{0}+\beta \lambda \mu_{1} M S T_{h f t}-\beta \lambda \mu_{2} D_{h f}+\lambda M_{h f t-1}
$$

\section{Empirical Specification and Estimation Results}

This study applies the model of Hatton (1995) to analyse the factors determining intra-ASEAN migration. One modification is the use of panel data, which consists of a cross-section of data from nine countries migrating to Thailand, and time-series data collected annually in the period 2002-2010, nine years in total. Thus, the number of observations employed in this present study is 81 . The data is from the 'Office of Foreign Workers Administration', and the 'Thailand Overseas Employment Admission', the Department of Employment, Ministry of Labour, Thailand. The dependent variable is net migration rate, which results from dividing net migration (inflows minus outflows) form countries in ASEAN (h) to Thailand, by the migration stock of countries in ASEAN (f) (Fertig, 2000; Hatton, 1995). Independent variables, real wages, $\mathrm{w}_{\mathrm{h}}$ and $\mathrm{w}_{\mathrm{f}}$ are approximated by the per capita income of the countries in ASEAN and Thailand, respectively. Per capita income in power parities is provided by Fetig (2000) and Maddison (1995), and is used to account for the difference in living costs between Thailand and other ASEAN state members. Employment rates $e_{h}$ and $e_{f}$ are equal to $\left(1-u_{h}\right)$ and $\left(1-u_{f}\right)$, where $u_{h}$ and $\mathrm{u}_{\mathrm{f}}$ are the unemployment rates of respective countries, as published by the OECD. Furthermore, our model is extended by adding a dummy variable which concerns the migration worker policy of Thailand. This dummy variable equals one $(=1)$ if the policy, concerning migration workers from Myanmar, Laos and Cambodia, both with and without work permits, permitting work in Thailand, is implemented. Such a policy was in effect in only 2004 and 2009, so for the years other than these the dummy variable equals zero $(=0)$. Thus, equation (4) can be rewritten as equation (5):

$$
\mathrm{M}_{\text {hthait }}=\tau_{0}+\tau_{1} \ln \left(\frac{p g d p_{\text {thai }}}{p g d p_{h}}\right)_{t}+\tau_{2} \ln \left(\frac{e_{\text {thai }}}{e_{h}}\right)_{t}+\tau_{3} M S T_{\text {hthait }}+\tau_{4} D_{\text {hthai }}+\tau_{5} M_{\text {hthait }-1}+\tau_{6} P_{\text {hthait }}+\varepsilon_{\text {hthait }}
$$

Assigned

$$
\tau_{0}=\beta \lambda \mu_{0}, \tau_{1}=\beta \lambda, \tau_{2}=\beta \lambda \frac{z}{2}, \tau_{3}=\beta \lambda \mu_{1}, \tau_{4}=\beta \lambda \mu_{2}, \tau_{5}=\lambda
$$

$M_{\text {hthait }}$ is the net migration rate from countries in ASEAN (h) to Thailand at time (t); $p g d p_{\text {thait }}$ is per capita GDP (PPP) in Thailand at time (t); $p g d p_{h t}$ is per capita GDP (PPP) in countries in ASEAN (h) at time (t); $e_{\text {thait }}$

is employment rate of Thailand at time t, $e_{h t}$ is the employment rate of countries in ASEAN (h) at time (t);

$M S T_{h f t}$ is migration stock at time t, $D_{h t h a i}$ is distance between the two locations; and $P_{h t h a i t}$ is the migration worker policy of Thailand at time (t).

According to the theory, we expect estimated coefficients to have the following signs: $\tau_{1}>0, \tau_{2}>0, \tau_{3}>0$, $\tau_{4}>0, \tau_{4}<0, \tau_{5}>0$ and $\tau_{6}>0$.

Net migration of Thailand from countries in ASEAN depends upon: the difference of incomes between Thailand and the other countries in ASEAN, the remaining numbers of migrants in Thailand, and the distance between Thailand and the other countries in ASEAN. This can be considered from the correlation coefficient presented in table 2, showing that the three variables significantly correlate with the net migration rate of Thailand, from 
countries in ASEAN, at a 1\% significance level. They are per capita GDP PPP ratio, migration stocks and distance between the two locations. However, considerations from these relationships cannot clearly describe which variables are the factors of change. The next inferential analysis will therefore explain such causes and effects.

Table 2. Descriptive statistics and correlation matrix of the studied variables

\begin{tabular}{|c|c|c|c|c|c|c|}
\hline Variable & $M_{\text {hthait }}$ & $\ln \left(\frac{G D P_{\text {thai }}}{G D P_{h}}\right)_{t}$ & $\ln \left(\frac{e_{\text {thai }}}{e_{h}}\right)_{t}$ & $M S T_{\text {hthait }}$ & Mean & S.D. \\
\hline Net migration rate $M_{\text {hthait }} * 10,000$ & 1 & & & & 9.881 & 91.245 \\
\hline Log of per capita GDP PPP ratio $\left(\ln \left(\frac{G D P_{\text {thai }}}{G D P_{h}}\right)_{t}\right)$ & $0.744 * *$ & 1 & & & 0.407 & 1.407 \\
\hline Log Employment rate ratio $\ln \left(\frac{e_{\text {thai }}}{e_{h}}\right)_{t}$ & -0.084 & 0.173 & 1 & & 0.032 & 0.029 \\
\hline Migration stocks/10,000 $\left(M S T_{\text {hthait }}\right)$ & $0.577 * *$ & $0.454 * *$ & -0.139 & 1 & 7.997 & 19.853 \\
\hline $\begin{array}{l}\text { Distance between the two locations } / 1000 \\
\left(D_{h f}\right)\end{array}$ & $-0.553 * *$ & $-0.514^{* *}$ & $0.660 * *$ & $-0.330 * *$ & 1.356 & 0.686 \\
\hline
\end{tabular}

Note: Number of observations: 81, Number of cross-sections: 9, Period: 2002-2010; ** Significant at 1\%

In terms of inferential statistics, panel data is applied to analyse factors that determine net migration rate from countries in ASEAN to Thailand. The result in Table 3 shows that both F-statistic and Breusch-Pagan LM statistic are statistically significant at $1 \%$ level. This indicates that both fixed and random effect models are better than the pooled OLS model. Furthermore, the Hausman statistic is statistically significant at $1 \%$ level, which indicates that the fixed effect model is more suitable than the random effect.

By employing 81 observations via the panel data with the fixed effect model, the results obviously show that there are three factors which are statistically significant at $1 \%$ level. They are per capita GDP ratio of Thailand to ASEAN countries, migration stock, and migration worker policy. All of them have a positive relationship with the net migration rate from countries in ASEAN to Thailand. These results coincide with the aforementioned hypotheses.

Contrast, there are two factors that are statistically insignificant, employment ratio and lag net migration. For employment ratio, the sign of the coefficient is as predicted, but its magnitude is not statistically significant. This might be due to the continuously low rate of unemployment in Thailand. For instance, the highest unemployment rate during the period of study is only $1.04 \%$ in 2010 . Therefore, the employment rate is unlikely to correlate with the net migration rate. This result is similar to that found in Hatton and Williamson's (2002) study. Lag net migration rate is another factor which is not statistically significant. This lagged net migration rate indicates that the decision to migrate does not depend it's the last year one. Perhaps it is owing to the migration worker policy which is not regularly implemented. As a result, the lag net migration rate cannot be used to predict the current net migration rate.

Table 3. Determination of the net migration rate from countries in ASEAN to Thailand, 2002-2010

\begin{tabular}{ll}
\hline Variable & Estimated Coefficient \\
\hline Log Per-Capita-GDP Ratio, $\ln \left(\frac{G D P_{t h a i}}{G D P_{h}}\right)_{t}$ & 227.12 \\
\hline
\end{tabular}




\begin{tabular}{ll}
\hline Variable & Estimated Coefficient \\
\hline Log Employment rate ratio $\ln \left(\frac{e_{\text {thai }}}{e_{h}}\right)_{t}$ & 46.97 \\
& \\
Migration Stock, $\left(\mathrm{MST}_{\mathrm{h} \text { thai }}\right)_{\mathrm{t}}$ & $(0.13)$ \\
& 0.21 \\
Lag Net Migration, $\left(\mathrm{M}_{\mathrm{h} \text { thai }}\right)_{\mathrm{t}-1}$ & $(3.18)^{* *}$ \\
& 0.04 \\
Migration Workers Policy, $\left(\mathrm{P}_{\mathrm{h} \text { thai }}\right)_{\mathrm{t}}$ & $(0.45)$ \\
& 68.17 \\
Constant Term & $(3.25)^{* *}$ \\
& -108.87 \\
No. of observations & $(-3.64)^{* *}$ \\
R-squared & 81 \\
Adjusted R-squared & 0.61 \\
F-test & 0.60 \\
Breusch-Pagan test & $\mathrm{F}(8,67)=8.28^{* *}$ \\
Hausman test & Chi2(1)=8.73** \\
\hline
\end{tabular}

Note: t-statistics in parentheses; $*$ sig. at $5 \%,{ }^{*} *$ sig. at $1 \%$.

\section{Conclusion}

The purpose of this paper is to analyse the determinants of migration from other ASEAN countries to Thailand during the period 2002-2010. We have developed Hatton's model (1995) for panel data via fixed effect estimations. The results reveal that the GDP gaps between Thailand and migrant countries, migration stocks reflecting the existence of a migration network, and Thailand's migration worker policies all significantly influence migration behavior. According to the results, the rising number of ASEAN migration workers to Thailand, searching for employment opportunities and human security, has been anticipated. This is because ASEAN will become the ASEAN Economic Community (AEC) in 2015, and there exists the mutual recognition agreement (MRA) about qualifications and standards of professionals for intra- ASEAN skilled labour mobility. However, foreign worker policy implications of the Thai government should have more continuity. This study could serve as fundamental information for further policy making and policy measures. In addition, the effects of foreign worker migration upon the Thai economy as a whole should also be deeply investigated.

\section{References}

Bodvarsson, O. B., \& Berg, H. V. (2009). The economics of immigration: Theory and policy. Springer, New York.

Borjas, G. J. (1987). Self-selection and the earning of immigrants. The American economic review, 77(4), 531-553.

Fertig, M. (2001). The economic impact of EU enlargement: Assessing the migration potential. Empirical Economics, 26(4), 707-720. http://dx.doi.org/10.1007/s001810100078

Hatton, T. J. (1995). A model of U.K. emigration, 1870-1913. Review of Economics and Statistics, 77(3), 407-415. http://dx.doi.org/10.2307/2109903

Hugo, G. (2005). Migration in the Asia-Pacific region. Retrieved from http://www.migrationpolicy.org/article/migration-asia-pacific-region/

International Monetary Fund. (2011). World economic outlook report. Retrieved from http://www.imf.org/external/pubs/ft/weo/2011/01/weodata/index.aspx

Lee, E. S. (1966). A theory of migration. Demography, 3(1), 47-57. http://dx.doi.org/10.2307/2060063

Messey, D. S., Arango, J., Hugo, G., Kouaouci, A., Pellegrino, A., \& Taylor, J. E. (1993). Theories of Internal 
Migration: Review and Appraisal. Population and development review, 19(3), 431-466. http://dx.doi.org/10.2307/2938462

Ministry of Labour, Department of Employment, Office of Foreign Workers Administration. (2011). Remaining numbers of foreigners with work permission in Thailand as of December 2006-2011. Retrieved from http://www.overseas.doe.go.th/statistic.php

Ministry of Labour, Department of Employment, Thailand Overseas Employment Admission. (2011). Numbers of Thai laborers emigrated within ASEAN countries in 2005-2011. Retrieved from http://www.overseas.doe.go.th/statistic.php

Priore, M. J. (1979). Birds of passage: Migrant labour in industrial societies. New York, NY: Cambridge University Press. http://dx.doi.org/10.1017/CBO9780511572210

Pytlikova, M. (n. d.). Migration flows from the perspective of sending and receiving countries. Australia: Ph.D. Thesis, Aarhus University.

Ravenstein, E. G. (1885). The laws of migration. Journal of the royal statistical society, 48(2), 167-235.

Ruyssen, I. (2008). The determinants of immigration to Western Europe 1996-2005: A panel data analysis. Ghent University, Working Paper.

Schultz, T. W. (1961). Investment in human capital. The American economic review, 51(1), 1-17.

Stark, O., \& Taylor, E. J. (1991). Migration incentives, migration types: The role of relative deprivation. The Economic journal, 101(408), 1163-1178. http://dx.doi.org/10.2307/2234433

The World Bank. (2011). GDP per capita based on purchasing power parity (PPP). Retrieved from http://data.worldbank.org/indicator/NY.GDP.PCAP.PP.CD

\section{Copyrights}

Copyright for this article is retained by the author(s), with first publication rights granted to the journal.

This is an open-access article distributed under the terms and conditions of the Creative Commons Attribution license (http://creativecommons.org/licenses/by/3.0/). 